\title{
7 Christian Narratives About Bulgarian-Speaking Muslims
}

Unlike many Muslim narratives about Christianity and Christians, Christian comments and interpretations do not typically rely on sacred or mythical narratives. When explaining the origins of Christian rituals, Christians include no references to events taking place in illo tempore or in biblical times, and Christian attitudes towards Islam are not expressed in terms of the foundational events or figures of Christianity. Most of my Christian respondents appeared to be largely uninterested in Islam (some were barely familiar with the name of Muhammad); Christian interests were mostly centered around the identity of Bulgarian-speaking Muslims, namely whether or not they were actually Bulgarians.

Although some of the narratives questioned whether Bulgarian-speaking Muslims could be legitimately considered Bulgarian, those were in the minority; most narratives emphasized the supposed Bulgarian identity of Bulgarian-speaking Muslims. Bulgarian Christians are generally ambivalent about Bulgarian-speaking Muslims, a group they regard as something as a taboo topic (in the sense proposed by Mary Douglas as “a matter out of place”, Douglas 2001, p. 41). This reflects the fact that the Pomaks cannot be easily classified as members of the Bulgarian nation. They are described by Christians as "Bulgarians turned Turk" (poturcheni): people who, though not actually Turkish, are not baptized and therefore cannot be considered Bulgarian. Both groups seem to regard baptism as the necessary precondition for Bulgarian identity and treat the terms "Christian" and "Bulgarian" as interchangeable. If mentioned at all, the concept of a Bulgarian Muslim identity usually takes the form of the endoethnonym "Bulgaromohammedans" (Bŭlgaromahomedani).

This ambivalence of my Christian respondents about their Muslim neighbours can be explained in terms of the specific nature of social identity, which Marilynn B. Brewer argues involves reconciling the opposed psychological needs of assimilation and differentiation (Brewer 1999, cited in: Brown, Zagefka 2005, p. 56). Depending on which of those needs becomes pre-eminent, Christians tend to come up with narratives which either affirm or bring into question the Bulgarianness of the Pomak population. Affirmative narratives describe the Pomaks as a familiar local group which shares a number of characteristically Bulgarian qualities; in this perspective, the Pomaks are seen as crypto-Christians. The negative narratives present the Pomaks as an eastern (Ottoman) population, a people "turned Turk".

Interestingly, Christians who are willing to ponder Pomak identity seem passive and uninterested in examining their own religious identity, which they take as a given. Unlike Muslims, Christians do not tend to see the other group as an "Other”, in relation to whom they need to define their own identity.

The comments made by Christians in this chapter must not be treated as sources of reliable information about Muslims; if anything, they are a source of ethnological 
information about the Orthodox Christians themselves. As Joanna TokarskaBakir writes, "the qualities attributed by a group to the Other are antithetical to an idealized image of one's own group. In this sense, stereotypes yield data about the stereotyping group, its culture and historical period, and not about the stereotyped group. The exact qualities incorporated into a stereotype are shaped by social change and historical circumstance. Some are results of actual interactions and individual experience, but stereotypes can also be perpetuated, revived or shaped by messages containing a culture's fantasies, regardless of whether the [stereotyped] group is present in that society or not" ${ }^{413}$ (Tokarska-Bakir 2008, p. 56-57, translation from Polish). In the material discussed in this chapter, stereotypical opinions about the Pomaks are largely shaped by folklore, particularly by folk songs telling the story of Bulgarian people "turned Turk" or heroically resisting this fate under Ottoman rule.

\section{1 "Purest-Bred Bulgarians" or "Conformists and Traitors"?}

One immediate ethnographic problem in discussing Bulgarian-speaking Muslims with Christians involves the naming conventions. The choice of a particular ethnonym out of the several possible options entails a considerable amount of information about the speaker's attitudes towards the group and the depth (or otherwise) of critical reflection on the relations between the groups. Recent democratic changes have pushed some ethnonyms to the margins in everyday speech as they become replaced by more politically correct equivalents. Some seem to be going out of use altogether. My respondents use ethnonyms such as Pomatsi, Bŭlgaromahomedani, Bŭlgari mahomedani or, sporadically, Bŭlgaromyusyulmani. Although Muslims may occasionally use some of those terms for purposes of self-identification, they are all essentially exoethnonyms.

Another term attested in my field research is kadŭna/kŭdŭna (Turkish: kadın) ${ }^{414}$, meaning a Turkish woman or a Bulgarian-speaking Muslim woman.

S.: Actually, they are kŭdynite.

M.L.: Does that word mean anything?

S.: Well, it means they're not Bulgarians, they're more like Turks. But they're not Turks. They're Bulgaromohammedans.

413 Tokarska-Bakir is referring to the ideas of L. Gilman in Difference and Pathology. Stereotypes of Sexuality, Race and Madness, Ithaca-London 1990, p. 16-29.

414 Literally, "woman, matron, lady". Since the late 17th century the term came to include harem (Arabic: harim) women who had given birth to the Sultan's children (Todorova 2004, p. 480). 
M.L.: But you said they were not Bulgarians?

S.: They're not. Maybe their great-grandmothers were Bulgarian, but they'd got turned Turk... We spent five hundred years under Turkish occupation.

M.L.: Do they realize that that's the case?

S.: How could they not?! People talk about it, you can read about it in books. Nowadays a very simple person might perhaps not have read about it, but they would have heard about it somewhere. (W, Ch, Interview 35, Garmen 2006)

My female respondent takes it for granted that books are a conclusive authority on the identity of Bulgarian-speaking Muslims, their own opinions in the matter being very much of secondary importance.

The term "Bulgaromohammedans" seems to be the most popular ethnonym denoting Bulgarian-speaking Muslims and one that is an "experience-near" concept ${ }^{415}$ (Geertz 1983, p. 57 to the respondents. Etymologically, the word is derived from the name of Muhammad but some respondents seem unaware of the fact, and they fail to realize its political incorrectness. They describe Bulgarian-speaking Muslims as "Bulgaromohammedans" when highlighting their Bulgarian identity as opposed to that of other Muslims living in Bulgaria:

M.L.: Why are the Pomaks called that?

M.: Because they're Pomaks. (W, Ch, Interview 34, Garmen 2006)

M.L.: But why do young people call them Muslims and older people I asked called them Mohammedans? Why is there such a difference?

K.: I don’t know why. We say "Muslims” because they embrace the Muslim religion. They say Mohammedans because in practical terms Pomaks are Christians "turned Mahommedan" (pomohamedancheni) $)^{416}$. They've known that for a long time, and I guess that's why they use the term, I don't know. I've never thought about it. (W, Ch, Interview 37, Garmen 2006)

M.L.: But why do they recognize Muhammad? Do you know anything about him?

S.: No, I know nothing about Muhammad. I know the name Muhammad. There are such [names - M.L.] (W, Ch, Interview 35, Garmen 2006)

415 A concept used by respondents "naturally and effortlessly to define what he or his fellows see, feel, think, imagine, and so on” (Geertz 1983, p. 57), borrowed by Geertz from the psychoanalist H. Kohut. Although my responents have gained more awareness about terms like "Pomaks" or "BulgaroMohammedans", they continue to use them out of habit in colloquial interactions: the terms are "experience-near" and persist even though the speakers are aware that this group would not choose to describe itself in such terms.

416 My respondents use the term in the sense of "Islamicization", a term they never use. 
My respondents are familiar with the term "Bulgaromohammedans" and continue to use it even though they are aware that the word has been fading out of use since the collapse of Communism in Bulgaria. Some Christians use no ethnonyms at all when referring to Pomaks, simply describing them as "Muslims" (a choice mostly preferred by the Bulgarian-speaking Muslims themselves):

\section{M.L.: I'd like to understand how the local Muslims came here?}

Y.: So, maybe they've been here for a long time, for centuries. And we've always been a mixed community. But back then we didn't call them "Muslims", they used to be called "Bulgaromohammedans". And we lived together. I've lived in such areas ever since I can remember ...

M.L.: They're no longer called “Bulgomohammedans” today?

Y.: Today, in democratic Bulgaria, they're not called Bulgaromohammedans, they're called Muslims. But it doesn't matter. People can use any name they like. You can practice any religion you like. You can believe whatever you like, this is... A person's individual choice. Whatever you like. (W, Ch, Interview 28, Satovcha 2005)

In casual interactions, the term "Muslims" is quite recent and the least frequent. It is regarded as vague and ambiguous because it applies to the Turkish minority as well.

Though less popular, the enthnonym "Pomaks" is also used, though Christians seldom use it in the presence of Bulgarian-speaking Muslims as some Muslims regard the word as offensive. Most Christians seem unaware that Pomaks resent the term, which implicitly characterizes their group as a victimized population coerced to embrace "the religion of slaves". Not all of my Christians respondents agreed with this perception. According to the respondent quoted below, the etymology of the word implies solidarity with, rather than contempt for, the supposedly victimised population:

M.L.: And when... when you use the word "Pomak", do people take offense?

G.: They do. Some of them do. It's... do you know which ones are offended? Again, it's those older ones, it's people who don't know the etymology of the word "Pomak", who don't know that it's... that it derives from the word "tortured" (pomûcheni)... In fact, the word is not derogatory at all. On the contrary. It has certain positive connotations: those are people who need help, people who deserve sympathy. They don't understand that. They just know that the word "Pomak" is offensive, and that's that! (W, Ch, Interview 23, Satovcha 2005)

The same respondent, a school teacher of Bulgarian, associates the word "Pomak" not with forced conversion to Islam, but to the persecutions suffered by the local population during the „revival process”, enacted under the Communist government of Todor Zhivkov: 
G.: The word itself has no insulting connotations, it connotes things like agony, suffering. A "Pomak" means a tortured person, a person who's gone through an ordeal. And those people may well have suffered more in the revival process than their ancestors did when they faced conversion to Islam. That's how I see it. My parents or the old people I've spoken to never mentioned any massacres, deaths or torture in Satovcha in the period when some of those people were converted to Islam. Which means that people were free to choose. (W, Ch, Interview 23, Satovcha 2005)

This comment is symptomatic of changing perceptions of the local historical experience, reflecting Bulgaria's democratic transition and the recent changes to the country's language and history curricula.

In the case of my Christian respondents, the term "Pomak" is usually linked with statements concerning the group's conversion to Islam, a fact which gets interpreted in one of two different ways. One interpretation sees conversion in terms of symbolic defilement: "turning Turk" is an act of shameful conformism, a sign of moral weakness and, according to some, shrewd self-interest: the Pomaks are people who allowed themselves to be "turned Turk" - unlike the ancestors of my Christian respondents, people with a strong moral backbone who successfully resisted the lure of conformism and profiteering.

Such ideas about the choices of ancestors threatened by Islamicization are mostly based on Bulgarian folklore, whose heroes often choose death over religious conversion. Educated or not, many of my respondents were able to quote passages from folk songs to support their arguments. College-educated people could quote specific songs and identify them by title; older people with a primary education (7-8 years) or an elementary education (four years) tended to unwittingly conflate various songs, which they treated as sources of absolute historical truth. Folklore, as the Bulgarian scholar Olga Todorova notes, "foklore is a highly dubious source of historical reconstruction” ${ }^{417}$ (Todorova 2004, p. 245), but ordinary people tend to find folk stories far more attractive than the dispassionate scholarly analyses of religious conversion patterns shaped by factors such as economic self-interest or upward social mobility.

One such vivid passage quoted to me by a female teacher of Bulgarian in Satovcha comes from the folk song, "Davash li, davash li, Balkandzhi ${ }^{418}$ Jovo"419 $^{4}$, in which the hero choses mutilation over marrying his sister off to a Turk:

G.: "Do you, oh do you give up, Balkandzhi Jovo, the beautiful Yana, so she accepts the Turkish faith? Hey, commander [Bulgarian: voyvodo], I give up my eyes. I do not give up Yana for the

$\mathbf{4 1 7}$ This is not to say that there were no acts of forced conversion to Islam: such cases existed but were sporadic, as attested in the historical record from the Ottoman and post-Classical Ottoman period which also contain occasional hints of violence (cf. Todorowa 2004, p. 245).

418 Highlander.

419 My respondent explained that the story was also discussed in Bulgarian classes by mixed groups containing Bulgarian-speaking Muslims. 
Turkish faith ["Davash li, oh, davash li, Balkandzhi Jovo, hubava Iana na turska vyara? - More voyvodo, ochi ${ }^{420}$ si davam, Iana ne davam na turska vyara!”] (W, Ch, Interview 23, Satovcha 2005)

Another story of martyrdom popular in the area tells about a young girl who failed to realize that a group of Turkish men was drawing close because she was braiding her hair: rather than suffer sexual assault, the girl threw herself down from a high rock, an incident which supposedly gave the name to the nearby town of Pletena ("braided"). The story is also treated as illustrative of the way in which Islam was imposed on the local population in the Rhodopes. My respondent treated the story with a pinch of salt and described it as a legend, but she narrated the story with a straight face, and pointed out to me the exact spot from which the girl jumped to her death, treating the story as a historical source:

M.L.: How do they [the Pomaks] view it? Do they know how they came to be Muslims, or are there different versions?...

G.: Maybe they do. Maybe they do. But I think there's no... I mean... There is a local legend about Pletena and how people were being turned Turk. About Pletena. A pretty maid... A very pretty maid who had long hair down to her feet... So, they realize that some Turks are coming, they're entering the village in order to turn people Turk. She was combing her hair at that moment, and her mother says, "Braided or not, we need to get up and flee, the Turks are here." So, off she went, but the Turks were already in her house, now, you can see those rocks above Pletena, and she throws herself from those rocks. That's how Pletena got its name. Braided or not, she throws herself down... That's one of the versions. (W, Ch, Interview 23, Satovcha 2005)

When she finished, the respondent corrected her narrative, clarifying that no historical accounts of forced conversion to Islam existed in the region.

G.: So, this actually survives in legend, the Turks, the girls running away from them. But in fact there's no historical evidence of any compulsion in the area. There was none. It's not like, say, Batak - with massacres and so on. There was none of that here. I'm guessing the locals are softer in spiritual terms. They're more willing to submit than to resist. You don't get this strong spirit of struggle around here, quite on the contrary. On the one hand that's a good thing, on the other hand, not quite. But at the same time they're very strong in terms of character. They are hospitable, very hospitable. (W, Ch, Interview 23, Satovcha 2005)

By contrast, my older female respondents had no doubts about the account's veracity:

M.: There is a village next to us called Pletena. When they [Turks] came, a pretty girl climbed a rock overhanging the river, it happened high up in the mountains. Well, not exactly in the mountains, but it's a mountain village. When she realized the Turks were gaining on her... because the

420 In a different variant, "glava si davam”, "I give up my head” (life). 
thing is, she had this long hair, and she was braiding it. She was at home, standing in front of the mirror. In the morning, her mother noticed some Turks near the house, and she said, "[Whether your hair is] braided or not, daughter, we must flee". [Told her] to forget braiding her hair. They left the village, and there was a high rock there. I don't remember what happened to the mother, but she [the long-haired girl] jumped off the rock rather than be turned Turk.

M.L.: Is that why it's called Pletena?

M.: That's where the name comes from. (W, Ch, Interview 33, Garmen 2006)

Iordan I. Ivanov cites this version of the story in his Mestnite imena $v$ gotse-delchevsko (1996). Ivanov dates the events to the 17th century (cited in: Radushev 2005, p. 151), which is when the village allegedly changed its name, but this claim is not corroborated by historical sources. The name Pletena can be found in the earliest known records from the Nevrokop region, which mention Pletena, a village with ten Christian households, in 1444 (cf. Radushev 2005, p. 153). A different Ottoman source (1464-1465) lists inhabitants of Pletena whose names suggest a Bulgarian community (Radushev 2005, p. 153). Records from the 1530s mention thirty-one Christian families and eight firstgeneration Muslim families living in Pletena (identifiable as first-generation Muslims because the males are referred to as "son of Abdullah ${ }^{421}$ ) (Radushev 2005, p. 153). The village of Pletena disappears from official records in the 17th century as its population becomes all-Muslim and therefore exempt from per capta tax (jizyah).

Concerning the folk etymology of Pletena, Olga Todorova notes that "in contrast to Orthodox Church literature from the Ottoman period, which mostly focuses on male «pomyusyulmanchvaniya» [conversions to Islam] or attempted cases of enforced «pomyusyulmanchvaniya», Islamicization - compulsory or voluntary - in our oral folklore is mostly present as regards women” (Todorova 2004, p. 269, translated from Bulgarian). Conversion of males does not appear in folk narratives, which Todorova attributes to the fact that conversions of women posed a greater threat to social structures and human relationships. Women who converted to Islam "became permanently unavailable to Christian males" (Todorova 2004, p. 270, translated from Bulgarian). The problem that did not affect men, as Muslims were allowed to marry Christian women under Islamic law.

In contrast to the idea of conversion as a stigma and a product of moral pusillanimity, my respondents are also familiar with a heroic vision of that phenomenon, which appears in Anton Donchev's well-known novel Vreme razdelno (“Time of Parting”, 1964). The novel, which is required reading in Bulgarian schools, presents a Christian priest who has to make a decision whether to accept conversion to Islam, and decides to side with life. Ludmil Staikov made the book into a film (Vreme na nasilie, [Time of Violence]), notoriously used as a propaganda tool during the „revival process” in the 1980s.

421 An assumed patronymic given to new converts in the Ottoman Empire. 
Similar to the folk songs, Donchev's novel shapes the Bulgarian post-memory of conversion to Islam in the Rhodopes. The decision to convert is portrayed in the novel as an act of heroism intended to protect Pomak women from rape, and thus to preserve the purity of Bulgarian blood. In this logic, conversion becomes the only way to preserve Bulgarianness (bulgarshtina). Accordingly, many of my respondents regard Pomaks as pure-blooded Bulgarians, a view which attests to the continuing popularity of this view, which goes all the way back to the ideas of Lyuben Karavelov, a 19th-century writer and national activist ${ }^{422}$ :

M.L.: What's the difference between "Muslims" and "Mohammedans”?

M.: The difference is that the latter are Bulgarians who were turned Turk. They never gave up their language, which essentially proves they're Bulgarian, they speak Bulgarian. But they accepted the Turkish faith. As a result, until quite recently they used to wear Turkish clothes, shalvari. Things are different now.

M.L.: You mean, we could describe the Turks as Muslims, but the Pomaks are Mahommedans (mahomedani)?

M.: Yes. The former are pure Turks. (W, Ch, Interview 33, Garmen 2006)

M.: They're stubborn people. They put up resistance when being turned Turk, but they failed. But to me they're still probably the purest of Bulgarians. (W, Ch, Interview 33, Garmen 2006)

This narrative is very closely tied to the idea that Bulgarian-speaking Muslims are in fact crypto-Christians, a subject to which I turn in the following section.

This recognition of the "purely" Bulgarian identity of Pomaks is not innocent on the part of my respondents: outwardly a mark of approval, this perception puts a symbolic claim on that group by negating its distinct identity. The evidence Christians cite in support of this claim includes shared customs and shared descent (cf. Bokszański 2005, p. 75), conservative rituals (preserved from time immemorial in an almost unchanged form), anthropological qualities (purity of blood caused by endogamous marriage arrangements in the local population), and purity of language (which is free from foreign borrowings and preserves many archaic forms).

E.: They have preserved family traditions much better than we have. They are subject to shared family laws. Those tends to be more interesting among the Pomaks, if you want to study Bulgarian traditions and customs, you should go and visit the Bŭlgaromahomedani. (W, Ch, Interview 37, Garmen 2006)

422 In Karavelov's view, those who allowed themselves to be “turned Turk" avoided rape and kept Bulgarian blood pure. My respondents did not offer this interpretation but they refer to Pomaks as "pure Bulgarians” (or even “the purest Bulgarians”). 
V.: Say, a small child is born and I want to visit my [female] neighbour with a povoika ${ }^{423}$. Our people do that too, but the Muslims make a much bigger point of keeping this tradition. Frankly, Muslims do a better job of keeping those traditions than we do. Even today, our people wouldn't do that sort of thing around here. When my neighbour's younger daughter-in-law died, the whole family gathered, she was 39 years old.

M.L.: Why?

W.: Because they have more respect for the family than we do. (W, Ch, Interview 11, Osikovo 2005)

The fact that many Muslims have Bulgarian surnames like those used in the Christian population is also treated as evidence of their Bulgarian identity:

Woman R.: They're Bulgarians like us. They’re Pomaks, not Turks.

Man I.: They have surnames like ours.

R.: Um, we don't talk much. Just the necessary stuff...

I.: You get [people named] Ushotsi living here and you get [people named] Ushotsi living in Debren. You get [people named] Uzunovtsi here, and [people named] Uzunovtsi in Debren.

M.L.: Why are those surnames the same?

I.: Because they used to be Bulgarians. Do you get it? Except they were turned Turk during the Turkish period, get it? Us, they couldn't turn Turk.

R.: They are Bulgarians, not Turks. They're Mohammedans, Bulgarian Pomaks. (Christians, Interview 40, Garmen 2006)

The idea that the Pomaks were an indelibly Bulgarian population "turned Turk", i.e. branded with a shameful stigma crying to be removed, was first made popular in 19th-century Bulgaria as a political pretext for liberating the Rhodopes from Ottoman rule (Brunnbauer 1999, p. 41). The notion continued to exert an influence in the 20th century, and was deployed in politically motivated assimilation campaigns aimed at the Pomak population (see Section 1.3.1.). An element of the official national canon for almost a century, the idea is connected with the belief that the Pomaks were forced to convert to Islam, a stubborn historiographical myth which persists despite the new historical evidence emerging since 1989. It seems that personal opinion (shaped by daily coexistence) has mixed with competing historiographies, ideologically motivated and promoted by the Bulgarian state in a top-down fashion in different

423 Also: ponuda - a custom in which female friends and neighbours bring food to a woman after childbirth. 
historical periods: the traditional narrative of Turkish oppression (with elements like massacres of Christian communities or forced conversion to Islam suffered by the Pomaks) and the post-1989 narrative of Turkish presence and voluntary conversions in the region. My respondents appeared to be conflicted about this discrepancy, and were not certain which was the more reliable one:

G.: What I meant was... Before 1989, people didn't talk much about the Turkish oppression. After 1989, people like the DPS and their kind tried to show the truth, or to distort it, I honestly don't know where the truth lies. Was there really any Turkish oppression? After all, we do have all that historical evidence, this many people slaughtered, this many women raped. The case of Batak alone is enough to prove that there was oppression. But after 1989 they say there was no Turkish oppression; there was "Turkish presence" instead. But there's a world of difference between Turkish oppression and Turkish presence! (W, Ch, Interview 23, Satovcha 2005)

M.: The way I had to teach this, it's called "Turkish presence" these days, and I taught it according to the textbook. (W, Ch, Interview 33, Garmen 2006)

On repeated occasions my respondents made ironic comments about the Pomaks as a group and criticized their identity choices. They emphasized the fact that Pomaks, who identify themselves as Turkish, tend to quickly lose their enthusiasm for Turkish culture when they actually have to learn Turkish. Similarly, some Pomaks reportedly dream of emigrating to Turkey, but they return to Bulgaria when faced with indifference in their adopted country. According to one respondent, Bulgarian-speaking Muslims complain about being treated as second-class citizens in Turkey, no better than Roma people:

M.: In the past they were turned Turk, accepted the Muslim faith. So, they said, we can convert, but we'll keep our language. So now they believe in Allah, the Muslim way, but they've kept the language, they speak Bulgarian. They don’t speak Turkish, they don't know a word of Turkish. Well, these days they tend to nag their kids, trying to get them to study Turkish, but that's like we used to study French... My daughter says they're offering Turkish classes in Debren but there's no interest, they've all dropped out. They can't memorize the vocabulary, there are no Turks locally, just Bulgarian-speaking Pomaks. Um, they have a few words, like makar or demek ${ }^{424}$, right? Big deal. (W, Ch, Interview 42, Garmen 2006)

Margarita: "They think the locals will be welcome if they move there", she says. "They call them Gypsies” - she says. - "They have no respect for them”. (Interview 42, Garmen 2006)

Some respondents claimed the Pomaks were suffering from an inferiority complex, believing that their Christian neighbours regarded them as unsophisticated rubes. When they come to visit a Christian, the respondent argued, Pomaks tend to act in a tense and awkward manner for no reason at all:

424 Both words are actually used in colloquial Bulgarian throughout the country. 
M.: When you come and visit ... I don't know what it is between us and them, maybe they have some sort of complex, like they're somehow inferior to us. You really have to make an effort to loosen them up (...).

M.L.: Why would you say they have a complex like this?

M.: Well, they feel unsophisticated.

M.L.: Why?

M.: I really don't know. You go and visit, and their houses are squeaky clean, and she [a Muslim female friend of the respondent - M.L.] wants to have the same kind of things that everybody else does, just look at Nada, how spacious her place is. Their houses are like palaces.

Dinka: A konak ${ }^{425}$. (W, Ch, Interview 42, Garmen 2006)

The respondents may be noticing the social withholding of acceptance or respect experienced by stigmatized persons, a reaction Erving Goffman describes as "the central feature of the stigmatized individual's situation in life". This reaction prompts stygmatized people to "echo this denial by finding that some of his own attributes warrant it", and to question personal qualities which were previously unquestioned (Goffman 1963, p. 8-9).

Reactions of those Pomaks who believe that Bulgarians see them as somehow defective fall into one of two types: 1) either they adapt and change their own image, for instance by giving up the traditional costume in favour of "European-style" clothes (either temporarily, when travelling away from their places of origin, or permanently, in which case they tend to react with embarrassment to fellow Pomaks wearing the traditional costume $\left.\mathrm{e}^{426}\right)$; 2) or they take pride in their religion and lifestyle, and reject the idea that they are a population historically forced to convert to Islam (implied in this attitude is the belief that Pomaks were Muslims even before the period of Ottoman rule in Bulgaria, a new ethnogenetic concept).

Whereas my Christian respondents can easily relate to the first type of reaction, they tend to be baffled by the latter variety. They find it difficult to clearly explain their own attitudes towards Bulgarian-speaking Muslims, or to recognize them as a separate ethnic group unrelated to Bulgarians.

Some people regard Bulgarian-speaking Muslims as a group caught between the Bulgarians (who they refuse to identify with) and the Turks (they sometimes identify themselves as Turkish but the Turks refuse to accept them as their own). Christians refuse to accept this identity choice of Bulgarian-speaking Muslims: they insist that

425 A large building.

426 As evidenced by the furore caused in 1994 by the film Gori, gori ogŭnche (dir. Rumiana Petkova, screenplay by Malina Tomova), cf. Lubanska 2006. 
Pomaks have nothing to do with Turks, an ethnically unrelated nation whose language they cannot speak. They find the Pomaks' stubborn refusal to accept a Bulgarian identity unreasonable and factually unwarranted:

M.: They've always been caught in two minds. ... We want them, they don't want us. They want the Turks, but the Turks don’t want them.

M.L.: Why do they want the Turks, but the Turks don't want them? Is it the language?

M.: They don't want that, I think that's because they are Bulgarians. Why would they want them, seeing as they're not Turkish? They're not even migrants in Turkey. (W, Ch, Interview 33, Garmen 2006)

M: Why are the Mohammedans ${ }^{427}$ called that?

S.: She's already told you, Magda did - they were opressed, they were turned Turk by force.

M.L.: But they're called Mohammedans, and not "people turned Turk"?

S.: Um, it's a name. They're not Turks. They don't have enough Turkish to buy a loaf of bread. (W, Ch, Interview 34, Garmen 2006)

G.: I mean, the interesting thing is that older Muslims consider it an insult to be called Bulgarian. They say they're simply Muslims, or Turks, or Pomaks. They will usually say they are Turks... though they have nothing to do with Turks. The thing is, they're not actually Turks. They're not ethnic Turks... But they’d never say, “We are Bulgarians”. (W, Ch, Interview 23, Satovcha 2005)

M.L.: Are Pomaks a different nationality?

I.: Yes, but they are mixed. Whereas Pomaks and Turks, they don't mix. The Turks don't want the Pomaks. (M, Ch, Interview 43, Garmen 2006)

E.: They pass this knowledge of past oppression from generation to generation, but they wouldn't admit that. What kind of religion is that...? It looks like the Turkish religion, they pray in mosques, but they're not Turks, they're not pure blood Turks. (W, Ch, Interview 37, Garmen 2006)

Some say openly that they would like the Pomaks to identify themselves as Bulgarian, though this concept of Bulgarianness is similar to the concept of American identity as a melting pot of different ethnic groups:

V.: I mean, just look at other countries. Everybody is free to practice any religion they like. And at the end of the day they say, "He's American". And that's it... Here in Bulgaria it's the same. Anyone can practice any religion they like, but we're Bulgarians, we are Bulgarians before all else, we live in Bulgaria. (W, Ch, Interview 28, Satovcha 2005)

427 I used the term “Mahommedan” because I was interested in my respondent's understanding of it. 
The respondent had reportedly heard a Pomak man complaining about fellow Pomaks who had rejected their Bulgarian roots:

D.: There is this one [Pomak] - he married a Bulgarian woman - and he speaks very ill of them [Bulgarian-speaking Muslims]. He says: “They're Pomaks, they're rubes”, he calls them all kinds of names. “They don't understand what you're saying to them. You tell him he's not a Turk, he's not a Pomak, he's Bulgarian - but he just digs his heels in! He will say: «That's what our grandmothers told us, and we'll stick with that!». There's no convincing them that they're Bulgarians". (W, Ch, Interview 41, Garmen 2006)

Another respondent said young people were more likely to identify themselves as Bulgarians, or as Bulgarian Muslims:

G.: Young people say... Young people make a distinction. We're Bulgarians because we live in Bulgaria, we speak Bulgarian, this is our nationality, but we have a Muslim religion. We are Bulgarians, that's who we are. (W, Ch, Interview 23, Satovcha 2005)

Christians also have a problem addressing Muslims who recently changed their Bulgarian names to Turkish ones:

V.: I can't call her Ayshe [a Muslim name recently taken by the respondent's female friend M.L.]. There's just no way you can spend 35 or 34 years calling a person by one name, and then suddenly call her something else. That's just ... not typical.

M.L.: What was the name before?

V.: Ani. I still call her Ani, and she doesn't correct me. When I call her Ayshe, it's like I'm talking to a different person. (W, Ch, Interview 28, Satovcha 2005)

Except when they object, the respondent prefers calling her Muslim friends by their former Bulgarian names. To the respondent's mind, a new name is a connection to a different person, and this changes a person's identity:

Y.: It’s something you do unwittingly.

V.: I have friends who say, "You've got to stop calling me Valia. Call me Fatme". I can’t spend 30 years knowing her as "Valia", and then one happy day just go and call her "Fatme". That's like listening to a different person, completely different. It's not a problem ... She doesn't make a big deal out of it... (W, Ch, Interview 28, Satovcha 2005)

My older respondents mentioned the embarrassment involved in an earlier rechanging campaign mandated by Zhivkov's government when Turkish names were being replaced by Bulgarian ones. In those day, my older respondents used to call their friends by their new Bulgarian names to avoid being fined: 
M.L.: When the names were changed, what did you call them then?

S.: We called them by their Bulgarian names. If I'd got caught using those [Turkish names - M.L.], who knows, maybe they would have fined me on the spot?

M.L.: What about today?

S.: Today you do what you like. Now it’s completely up to you.

Mariya: In the past they used to have two names.

S.: They still have two names today.

M.: Well, that's the times we live in. (W, Ch, Interview 34, Garmen 2006)

According to the respondent, the names used for addressing Muslims are a matter of personal choice, an observation my Muslim respondents confirm. For instance, a young hodzha from Ognianovo told me how he used to use two names as a child, an "official” name of Kamen, and a "family" name of Kizim. Reportedly, he did not mind it when other children called him Kamen (Interview 49, Ognianovo 2006). In 1990, he officially changed his name to Kizim.

When Bulgarian-speaking Muslims were being forced to change their Turkish names to Bulgarian ones, they sometimes named themselves after Christian families who had treated them well:

M.: All the girls in my class wanted to name themselves after me [the woman was a primary teacher in a religiously mixed class - M.L.]. Their parents came, and they asked me to explain to the girls that it wouldn't do to have so many girls with the same name in one class, how this would create chaos in the classroom. I told them, "Don't worry, it's your problem and you can handle it". "No, they say they love you, and want to have your name. If you tell them they will listen". And that's what happened. I've always loved children, I will probably go to my grave loving them. And children could always see that, and they loved me back. It's a feeling that enchriches my soul. (W, Ch, Interview 33, Garmen 2006)

\section{2 “Crypto-Christians” or Poturcheni (“People turned Turk”)?}

Christians believe that the Pomaks are living with a hidden sense of guilt because they had betrayed their religion which they long, deep down, to embrace again, or indeed continue to practice in secret. On the other hand, they believe Pomaks are drifting away from their Christian and Bulgarian roots because they are committed Muslims with recognizably eastern customs. Though mutually exclusive, those two perspectives seem to become conflated by some respondents, and should be seen as inter-related. 


\subsubsection{The Pomaks as Crypto-Christians}

Crypto-Christianity - the secret practice of Christianity by an outwardly Muslim population in the Ottoman Empire - was an historical phenomenon occuring between the 16th and the 19th centuries. There is nothing to indicate that the phenomenon still exists today.

According to Noel Malcolm, crypto-Christianity involved ${ }^{428}$ a degree of mimicry and camouflage, evident in the strategic marriage arrangements of the crypto-Christian community (cf. Malcolm 2001, p. 92): most converts to Islam were males, who chose Christian wives capable of ensuring the continuity of Christian traditions at home. Because Islam permitted marriages with Christian (or Jewish) women, the practice provoked no suspicion and was relatively widespread in the Ottoman Empire. In the case of crypto-Christianity, "apparently ... this system of religious differentiation by sex could be continued down the generations. It may thus have been an important mechanism in making crypto-Catholicism possible. With women in the family who are officially Christian, it became possible for priests to enter their homes in order to minister in secret to the menfolk as well” for purposes like christenings or other sacraments (Malcolm 2001, p. 100). Such religious practices could be kept secret so effectively that "sometimes the father does not reveal himself as a Christian to his sons, or the sons to the father, and on their deathbeds they behave as, and give themselves out to be, Muslims" (Malcolm 2001, p. 102). Another factor favoring crypto-Christian practice was the cooperation of the Christian clergy ${ }^{429}$, who were willing to administer the sacraments clendestinely ${ }^{430}$ (cf. Malcolm 2001, p. 100).

There are some historical accounts, although not many, of a crypto-Christian presence in certain communities of the Ottoman Empire. In his article CryptoChristianity in the Balkan Area under the Ottomans (1967), Stavro Skendi argues that crypto-Christianity was practised most openly in Cyprus: the local population converted to Islam in the 16th century, but for four centuries its members continued to baptise their children, give them double names (Christian and Muslim), practice fasts and adoration of the Eucharist, and marry women who could cultivate the Christian

428 It is important to bear in mind, however, that his analysis focuses on Kosovo and Albanian practices.

429 N. Malcolm writes about the Catholic clergy and does not discuss Orthodox Christian attitudes about crypto-Christians.

430 This despite the existence of church edicts criticizing crypto-Christianity and barring cryptoChristians access to the sacraments. N. Malcolm cites examples from Albania, such as a local synod convened in 1703 by Archbishop Vicko Zmajević, as well as other synods convened by the the Holy Office in 1724 and 1730 and by Pope Benedict XIV in 1744. (cf. Malcolm 2001, p. 101). Those had little impact on the activities of the lower clergy. Those members of the clergy who followed the Church policy were often conflicted about it. Archbishop Matija Mazarek feared that crypto-Christians denied the sacraments could turn into enemies of the Church and more zealous Muslims (cf. Malcolm 2001, p. 103). 
traditions (Skendi 1967, p. 230). Historically, scholars have uncovered evidence of crypto-Christian communities in Crete, Albania ${ }^{431}$, Serbia and Bosnia (Skendi 1967) as well as in Macedonia ${ }^{432}$ (Malcolm 2001, p. 103).

Although there are no credible accounts of crypto-Christianity in Bulgaria, Skendi does not rule out this possibility (Skendi 1967, p. 234). It seems probable that there were some self-identified secret Christians among first-generation converts. According to Noel Malcolm, crypto-Christianity proper applies "only when the attitude has become transmitted down the family, and established as a tradition, can we speak confidently of the practice of crypto-Christianity" (Malcolm 2001, p. 98).

Claims that the Bulgarian-speaking Muslims in Bulgaria were in fact cryptoChristians were often made in the writings of 19th-century travellers (e.g. Felix Philipp Kanitz), journalists, politicians and scholars. According to an anonymous writer for the Dunavska Zora journal who signed himself as "C", when Bulgarian Muslims named their children they would first invite a Bulgarian Christian to act as a godparent (cf. Raychevski 2004, p. 47). Stefan Verkovich ${ }^{433}$ wrote that many of the Bulgarians who have been "turned Turk" had kept their Christian names (Verkovich 1860, cited in: Raychevski 2004, p. 32), Ivan Galaganov claimed that they had retained the tradition of carol singing (Galaganov, cited in: Raychevski 2004, p. 33), and Lyuben Karavelov claimed that they continued to revere many of the Christian saints. Karavelov referred to this population as "half-Christians" (arch. Bulgarian: poluhristyene) because "they speak no Turkish, and therefore the Qur'an is still a dead letter to them” (Karavelov, cited in: Raychevski 2004, p. 51, translated from Bulgarian). Jean H. A. Ubicini, a French historian and journalist, argued that the Pomaks had held on to "most of the customs, rites and superstitions of their Christian ancestors," pointing to the local cults of St. George, St. Dimitar and St. Nicholas, as well as the local population's reverence for springs of holy water (cited in: Raychevski 2004, p. 77, translated from Bulgarian). In times of illness, pestilence, fires or other disasters, wrote the Austrian journalist Otto Felix Kanitz, local Muslims preferred visits to local healers or former Christian holy places rather than consult hodzhas (cited in: Raychevski 2004, p. 69). In the same historical period, Hristo Popkonstantinov argued in 1878 that "The Pomaks consider themselves Turks or Ottomans, and so their brothers, Bulgarian Christians, lack the courage to tell them openly that their forefathers had practised a different faith, and they call them Turks” (cited in: Radushev 2005, p. 27, translated from Bulgarian).

431 Some scholars mention Kosovo in particular (Malcolm 2001).

432 Church and diplomatic reports to Rome and Western powers contain details and statistical data which lasts in some cases until the 1860s (Malcolm 2001, p. 103-105).

433 Bosnian Serb, archaeologist, folklorist in Macedonia who also worked as a secret agent of the Serbian government. He published two volumes of mythical songs: Veda Slovena. Bŭlgarski narodni pesni ot predistorichna i predhristyanska doba (Belgrade 1874) (featuring folklore of Slavic Muslims), and Narodne pesme makedonski bugare (1860). 
It is no longer possible to ascertain the reliability of those 19th-century sources but they seem to be overestimating the strength of crypto-Christianity: it is otherwise difficult to account for the large-scale wave of Bulgarian-speaking Muslims openly re-embracing Muslim names and costumes in 1913 after being forcibly Christianized by the Bulgarian clergy in $1912^{434}$ (Neuburger 2004, p. 41). According to Frederik W. Hasluck, writing close to those events in the first half of the 20th century, the idea of crypto-Christianity was so popular because European travellers knew little about Islam in Asia Minor, and attributed any departures from Sunni orthodoxy to surviving Christian belief among the native population converted to Islam (Hasluck 2005, p. 125). As Hasluck noted, "though crypto Christians exist in Asia Minor, many, if not most, of the unorthodox practices obtaining amongst tribes supposed to have been originally Christian, are in fact to be referred either (1) to the primitive stratum of religion, which survives in superstitious practice among Christians no less than Mohammedans, or (2) to the Shi' $\mathrm{h}^{435}$ branch of the Mohammedan faith, which, though orthodox in Persia, is to the Sunni Turks quite as much outside of the pale as the Christianity of the Armenian is to the Greek or vice versa” (Hasluck 2005, p. 125). Hasluck suspected that many Turkish tribes had encountered the local form of Islam when migrating westwards through Persia, which could be seen as a link between Islam and paganism (Hasluck 2005, p. 125). Although Hasluck's evolutionist approach is very much of its day, his conclusions often appear to stand the test of time.

As demonstrated in Bulgarian historiography, the idea that Bulgarian-speaking Muslims were in fact crypto-Christians is strongly connected with nationalist political propaganda going back to the second half of the 20th century, and often used in the context of assimilation campaigns (see Chapter 1). Today, this view is represented by the Bulgarian historian Petar Petrov (Nepokorni podanŭtsi na sultana [The Sultan's unruly subjects], 1995), the lectures of ethnographer Krasimir Stoilov ${ }^{436}$, former political activist Petar Djulgerov in Razpnati dushi [Crucified people, 2000] or Boyan Saryev, an Orthodox priest of Pomak descent active in the Eastern Rhodopes (a highly

434 At the time, Bibles, crucifixes and Bulgarian headgear were distributed among the population to replace the fez and the zabradkas (cf. Neuburger 2004, p. 41). This is notable in the context of the widespread belief in the local area that Bulgarian-speaking Muslims are still secretly holding on to those objects, which they keep hidden in their attics.

435 F.W. Hasluck had an evolutionistic interpretation of Shi'ah Islam as a link between paganism and Sunni Islam.

436 Among others, Stoilov gave his lectures at the Institute of Ethnology and Cultural Anthropology, University of Warsaw as a visiting lecturer in 2002 and 2006. Stoilov's examples of crypto-Christianity included Muslim women making a cross-shaped gesture over freshly kneaded dough, crucifixes found in the graves of Bulgarian-speaking Muslims or crosses engraved in stones placed in foundations of houses. Those observations supposedly confirm the Bulgarian identity of the Bulgarian-speaking Muslims by diminishing their distinctive features. 
controversial character and a former agent of the Bulgarian Security Service ${ }^{437}$ who wrote Glasŭt na vikashtiya na pustiniyata [A voice of one calling in the wilderness, 1996]. Another notable example of this kind of writing is the recent book by Stoyan Raychevski, Bŭlgarite mohamedani [Bulgarian Muslims, 2004], which uses 19thcentury sources to argue that the Pomaks are ethnic Bulgarians, blithely ignoring the actual religious practices or personal opinions of the Bulgarian-speaking Muslims in question.

Importantly, a distinction needs to be made between crypto-Christianity taken to mean a historical phenomenon, and the narrative of crypto-Christianity used as a way of symbolically claiming the Other by negating the Other's separate identity. By invoking the crypto-Christianity narrative when talking about the Bulgarian-speaking Muslims, Christians imply that the Islam practised by their neighbours is no so much a distinct, independent religion as a kind of facade hiding their continued attachment to Christianity. In doing that, Christians seem to be confusing secondary cultural practices (as when Muslim women mark bread dough with a cross before putting it in the oven) and their religious meaning, a phenomenon Hasluck noted already in the 19th century.

Interestingly, my respondents believe that crypto-Christianity forms an important and deeply private aspect of Pomak life: practically the "most sacred" aspect of all, which is carefully kept from outsiders:

E.: I actually get the impression that the Muslims know Christianity better than Muslim religion. I'm talking about the Bulgaromohammedans. My impression is that deep down, in spiritual terms, they know and observe those things more [than actual Christians], even though they never show it ... They would never open up to you intentionally. To them, those things are holy. (W, Ch, Interview 37, Garmen 2006)

To Christian respondents, this alleged crypto-Christian identity is especially apparent in the emotional attachment felt by Pomaks towards Christian cult objects such as icons, crucifixes or Bibles, which they supposedly venerate on Christian holidays:

E.: This used to be a Bulgarian village before it was turned Mohammedan. The old people, her mother died at the age of eighty... in their chests they all kept things like Bulgarian costumes, crucifixes, everything. On Christian holidays they took those things out and kissed them. Once there was an expedition [field research trip] in this area, and that's what they concluded. Very interesting. Today this has all got very political. They've moved apart, they've hidden those things away. They don't talk about it. But deep down perhaps they nurture it in their soul. They know where their roots are, they know that very well. But nowadays many politicians have started exploiting people's feelings, so people just clam up and keep those things in their hearts, they don't talk about it. (Interview 37, Garmen 2006)

437 Saryev was often mentioned by my Christian respondents, who see his story as confirmation of the thesis that Bulgarian-speaking Muslims are in fact Bulgarians. 
My respondents argue that Pomaks have been keeping Christian cult objects for generations, usually hidden in dowry chests (which suggests matrilineal transmission):

Archimandrite Grigoriy: ... They've kept chests which used to belong to their grandfathers or grandmothers, from the olden days. In those chests they always keep crucifixes or icons. (Interview 27, Satovcha 2006)

According to another respondent, Pomaks often keep traditional Bulgarian costumes in the chests:

V.: Old ladies keep Bulgarian clothes in those chests.

M.L.: Really? Have you seen that?

W.: I have. (M, Ateist from Christian background, Interview 47, Garmen 2006)

Some of the Bulgarian-speaking Muslims who have preserved such Christian cult objects are referred to as "priests":

M.: Twenty-two years ago I went to one such village on official business. I know them. A man used to live there, they called him "the priest" [pop, otets]. He'd died some years before, but I asked some older people... That was a secret 60 years ago, when... 50 years. People used to feel differently about their identity. They didn't talk about that, they kept it under wraps. They called him "the priest" because he had a Bible and an icon that he kept hidden away. I'm not sure if you know the word "chest"? It's like a large decorative box. Something like a gift for the bride, for keeping valuables. At the bottom [of that chest] there was an icon and a Bible.

M.L.: Even though he was a Muslim?

M.: Yes. (W, Ch, Interview 33, Garmen 2006)

Another female respondent mentioned a friend, a Bulgarian-speaking Muslim woman, who reportedly complained that her children no longer believed in their Christian roots because they were so "steeped in Pomak ways", a situation which threatens to end the passing down of Christian objects from generation to generation in Pomak families.

M.L.: And what is the difference [between the Turks and the Pomaks - M.L.]?

D.: So, Turks know and understand the Turkish language, but our local Pomaks of Debren speak no Turkish. They're Bulgarian. And they became [Pomaks]. Like an old woman said, a kŭdŭna, as we call them: “... we are Bulgarians. My grandmother had a chest, a box where she kept her clothes and a crucifix. She was a pure Bulgarian,” she said. "And we've kept this crucifix, and we pass it down from generation to generation. My grandmother gave it to me, and I give it to my 
children, but nobody believes me, they're too steeped in those Pomaks ways”. (W, Ch, Interview 41, Garmen 2006)

In such narratives, Christians often discover this attitude of special reverence for Christian objects among their Pomak neighbours by accident. For instance, many such items were supposedly discovered by Bulgarian troops searching for hidden weapons in Pomak houses in 1944:

Man I.: I mean ... indirectly, after 9 August they were doing searches in houses, you know, they were looking for weapons in their homes, and what they found was candles, crucifixes, do you understand?

M.L.: Yes.

Woman R.: Right. They've got those ... those remnants of Bulgarian identity. Their ancestors were Bulgarians.

I.: And they have a lot of such remnants. They used to be pure Bulgarians. But... that's right... their religion was taken away from them by force. Our village held on, we're tougher people, you see, and so ... this place has remained purely Bulgarian. (Christians, Interview 40, Garmen 2006)

Christian burials in the older generations of Pomaks have also been cited as evidence of Pomaks' crypto-Christian identity, even though crucifixes found in old graves offer little insight into the religious identity of the Pomak population today. According to Archimandrite Grigoriy, old Pomak graves, which face east like those of Orthodox Christians, often contain Bibles, crucifixes and icons:

Archimandrite Grigoriy: I mean, on the other hand, many of them, when they dig up the graves of their grandfathers and grandmothers, they discover Orthodox Christian burials, with a crucifix and an icon, facing east. (Interview 27, Satovcha 2005)

Metropolitan Natanail of Nevrokop mentioned historical accounts of forced conversion to Islam, which led to the emergence of crypto-Christian Pomak communities whose members would come to confession, and even Communion, in the monastery at Hadzhidimovo, indicating a troubled conscience after abandoning Christ:

Metropolitan Natanail: We have historical knowledge of how the Rhodopes were turned Mohammedan. It's not from the oral tradition that we know how the monastery was first built. We have written data. But we know from oral tradition that the monastery had been set on fire on at least two or three occasions. The last time this happened was when people were being turned Mahommedan. Some of the people who were forced to embrace Islam came here not only Gergiovden or Easter but also on other holidays. To confess the sin of betraying Christ. When allowed to do so, some even took Communion. (Interview 62, Hadzhidimovo 2009) 
Nowadays some Muslims wear pouches containing pieces of paper with Christian prayers inscribed with the symbol of the cross, which the Metropolitan regards as proof of their crypto-Christianity:

M.L.: When they come here, do they ask for prayers?

Metropolitan Natanail: They do.

M.L.: I’ve seen a boy wearing a prayer written by a priest.

M.N.: Yes, it's a tradition that survives since those times.

M.L.: The times when they used to come here [to the monastery]?

M.N.: Yes, yes. Those times. What kind of genuine, true Muslim would wear a prayer with a cross drawn at the top?

M.L.: You mean, it's supposed to include the picture of a cross?

M.N.: Yes. (Interview 62, Hadzhidimovo 2009)

The Metropolitan ignored the context of the practice, which is a healing practice rather than a form of Christian worship. Other respondents used similar arguments, arguing that the practice of sleeping in churches or lighting candles suggests that the Pomaks are crypto-Christians:

Y.: Older people used to give us money to buy candles with, and to light them [to pray] for health.

\section{M.L.: Their health?}

Y.: That's right. Others would just leave money instead of lighting candles. They would just leave money on the collection tray and that's that. Others lit their own candles. (W, Ch, Interview 28, Satovcha 2005)

Perhaps surprisingly, consumption of pork is also treated as evidence of the supposed crypto-Christianidentity of Pomaks: Christians refer to situations where they witnessed Muslims either eating, or being offered, pork. Importantly in this context, Bulgarianspeaking Muslims were also forced to eat pork during the 1912 assimilation campaign to prove their conversion to Christianity had been sincere, the Christians treating the consumption of pork (in violation of a religious prohibition of the supposedly abandoned religion) to be more convincing evidence of conversion than the taking of the Communion - perhaps not the most Christian of sentiments, and certainly not one often discussed today.

When they mention it at all, Christians only mention situations where Muslims consumed pork voluntarily. The following respondent was reportedly shocked when 


\section{Muslim women attending a wedding party during the Ramadan ordered cabbage with pork:}

V.: I'd like to share a story about some of the Muslims. We went to "Bulgaria", it's a restaurant, it was a long time ago. I looked around the room, and sat next to them. At that point they hadn’t ordered yet. One was an elderly woman, the other one was young. The older woman said, "How about some baked pork and cabbage?” That was during the Ramadan. I was really shocked. Some people won't even eat bread, and here they were, ordering pork and cabbage. Eating pork. Muslims are not supposed to eat pork. But when you don't have... [the respondent laughs - M.L.]. I placed my order, feeling really shocked. That's what we are like; that's what they are like. Some people are observant, others are not. That's just how it is! You get priests who are like that, and hodzhas, too. A man will eat the very stuff he forbids others to touch. (W, Ch, Interview 11, Osikovo 2005)

Another respondent claimed that only the older Muslims did not eat pork $\mathrm{k}^{438}$ but the younger ones were unfazed when offered pork by Christians. Her husband's Muslim friends accepted his invitation to a pig-slaughtering party, and joined the couple for the meal that followed:

M.L.: Generally speaking, do they eat the same foods?

M.: They do, pork excepted. Um, the old people don't eat pork, but the young ones do. One of them said, “If I wasn't too embarrassed, I'd raise a pig in my own backyard”. One person helps himself [to a piece of pork], and others follow suit.

Dinka: My neighbours ask me, “Now, you wouldn’t have a bit of bacon left, would you?” “I do, actually, but what if your grandmother finds out?” "It's alright, she's going to have it without even knowing”.

M.L.: What about rakiya [brandy] or wine?

M.: They drink everything.

M.L.: Do they hide their drinking, or...?

M.: No, they have their bars. They don't hide their drinking, they eat bacon ${ }^{439}$. Gosho used to work with some men from Debren, and we were slaughtering a pig once, so he said, "I'll invite them over to the pig-slaughtering party". And they showed up. I said to a friend of mine, "What am I supposed to serve you lot? I've made a massive pot of pork and cabbage. What am I supposed to prepare for you, eggs?" "Are you mad, you have all this food, pork chops and everything, what

438 The respondents seem to be contradicting themselves by arguing that the younger Pomaks are more religious (and are therefore losing their crypto-Christianity), but also that the young Muslims are more likely to eat pork (and break the rules of their religion).

439 I use the word "bacon" as a rough equivalent of slanina, a type of fatty food popular in Eastern Europe and consisting of slabs of pork fatback (unlike bacon, slanina is not necessarily bacon-cured). 
do you mean, eggs?! ... Come on, I'll try everything”. They'll say no to fatty things, but in the end they end they eat everything... (W, Ch, Interview 42, Garmen 2006)

Christians claim that Pomaks like pork so much they sometimes invite themselves to Christian homes, hoping to be served pork dishes. Apparently, they do that in secret to keep their visits from fellow Muslims, particularly their wives and mothers ${ }^{440}$ :

M.: In the end, all the people at work, all of the workers were saying, "Bay Dancho, aren't you going to invite us over and offer us some pork dishes?" "Come over and have some if you like".

M.: "Tell your wife not to mention our visit to anyone”. And round they came, five or six people.

M.L.: Women too?

M.: They were men. They asked us to draw the curtains so nobody could see them inside. (W, Ch, Interview 33, Garmen 2006)

Apparently, some Muslims bring their own bacon when they visit Christian homes, and ask Christian housewives to prepare it so they can take the food home:

M.L.: Is it true that Muslims don’t drink?

M.: But they do, of course they do, they eat bacon as well, the whole works. There are fanatics as well. But when I was a teacher, years ago, they would bring me bacon and salami as New Year gifts. I'm not talking about today. Today, everybody buys and fries their own stuff. The old people forbid it but who listens to old people?! Today people are even more liberal. They'd bring me bacon for frying, and they shared it with me because we understand, we're friends. I told him, next time you get hungry, don't bring your own food, I've got loads of pork and bacon, no need to buy anything.

M.L.: Couldn't they prepare it at home with their elders?

M.: I asked him, "Izmir, why don't you buy it from the shop and ask your mother to fry it at home?" “That wouldn't happen in my dreams, if I tried to fry it at home she'd throw the pot and the frying pan out of the window”. So [he came to the respondent's house instead], so as not to upset her. (W, Ch, Interview 33, Garmen 2006)

The prohibition on pork in Muslim households is a problem for Christian women married to Muslims. According to my respondents, they often come and visit their relatives just to have some pork, like the daughter of a priest from Debren who married a Turkish officer:

I.: She used to come here, where her brothers and sisters lived, and asked them to give her bacon ... they raised pigs here, [she came to visit] whenever they were slaughtering a pig. Turks don't

440 Although it is supposedly women who hold on to Christian objects and pass them on to the next generations (see above). 
eat bacon. "Brothers, give me some bacon”. A kadŭna doesn’t eat bacon. (M, Ch, Interview 40, Garmen 2006)

Reportedly, Muslims who are too embarrassed to raise their own pigs sometimes outsource their pig farming to Christian neighbours in order to obtain pork for homemade salami (lukanka) - otherwise the salami is "too dry":

M.: They ask Christians to raise piglets for them. Then they slaughter the animals at the same time. They slaughter their calves, and our people slaughter the pigs. That's how you make salami, you use a blend of meats. Veal is no good on its own, the meat is too dry. If you want tasty salami you need pork as well. But the elders don't allow them [to raise pigs]. So we raise them for them. (W, Ch, Interview 33, Garmen 2006)

In those narratives, Christians are pleased to violate the religious prohibition and help Pomaks return to their roots. The stories are meant to bring to light the hypocrisy of the Bulgarian-speaking Muslims, who pretend to be pious Muslims in front of women (women are the preservers of Muslim values who pass them on to the new generation). In this situation Christian neighbours see themselves as people around whom their Muslim friends can really be themselves. Obviously, accusing a religious outgroup of hypocrisy is a way of bolstering the perceived value of the ingroup's own lifestyle.

There are also narratives in which Christians realize that eating pork is a sin for Muslims and would never serve them forbidden foods:

M.L.: When they come to visit, you don't serve them pork?

S.: No, they know I'd never serve pork to them. How could I make them commit a sin like that? That's just not right! (W. Ch, Interview 35, Garmen 2006)

Some Christians realize that eating pork is forbidden in the Qur'an:

M.L.: Are those things unclean to them?

M.: Yes, it's damus ${ }^{441}$. I've been reading bits out of their Qur'an, damus meat is prohibited to them.

M.L.: Damus, meaning pork?

M.: [All] pork, not just bacon. (W, Ch, Interview 33, Garmen 2006)

Some Christians realize that Muslims consider pigs to be unclean, but they explain the prohibition with a traditional joke (at the expense of Turks):

441 Turkish: domuz - pig, also: slob, messy person. 
M.L.: Why do they abstain from pork?

M.: Apparently, there's a legend that says some people were cooking a pig on the Turkish-Bulgarian border. "Whichever way the pig turns, that's how we divide the meat." "All right, then." However, the Turks got the backside. They were revolted, and refused to eat it.

Dinka: The rear end is the best part!

M.: They tend to eat veal or lamb instead. (W, Ch. Interview 42, Garmen 2006)

Today, the Pomaks continue to share the misguided reaction of those Turks. By pointing out that the (albeit insulting) back-end (hams) are the best part of the animal, the respondent emphasizes the bad choice made by the Muslims in the story. This joke may be a way of defusing the cognitive dissonance potentially present in the idea that Christians eat unclean meat by portraying this religious prohibition as unwarranted and preposterous.

Interestingly, the story is also known in the Turkish community. I heard a variant of the story from a Turkish woman in Dabnitsa. In that version, the Bulgarians are tricked into agreeing that they will get the animal whichever side it lies down on:

Turkish W.: There was a time when a lot of people were dying. People blamed pork, because it's a fatty meat and shouldn't be eaten. The Turks let a pig lose in the mud, and said, "If the pig lies down on its right side we won't eat it. If it lies down on its left side, then the Bulgarian Christians will eat it." And they waited. "Alright, so that's that. The Bulgarians will eat it”. (W, M, Interview 45, Dybnica 2006)

\subsubsection{The Pomaks: Poturcheni ("People Turned Turk") or "People of the Orient"?}

In other Christian narratives the Pomaks are portrayed in a very different light as their religious culture is stigmatized as being backward, Oriental, primitive and patriarchal. In this perspective, Christians view themselves as representatives of the Western world, and they perceive their Bulgarian-speaking Muslim neighbours as representatives of some unspecified "Oriental culture". According to one respondent, this culture is characterized by specifically "Oriental” ways of thinking, patriarchal social structures and a lack of commitment to the common good:

V.: Right, that's exactly the Oriental thinking. Meaning, my stuff is mine, and other people's stuff is common property. Something like that ... That's exactly what it says in the Qur'an. (W, Ch, Interview 28, Satovcha 2005)

The respondent compares Bulgaria's sorry state as a postcolonial country to the former colonies of the British Empire: 
Y.: It's Oriental thinking. You know, that's what I call it. I mean, we spent five hundred years living under Turkish oppression. We were unlucky [to be occupied by Turkey], the countries living under English occupation, those colonies, they're much more modern today, economically and mentally. They think differently. But Oriental thinking, how shall I put it, it's not unrelated to religion, to the Qur'an. (W, Ch, Interview 28, Satovcha 2005)

Men enjoy a privileged status in Pomak communities, a situation Christians find blatantly unfair to women. They illustrate this state of affairs with examples taken from everyday life. Iordanka from Satovcha made a comparison between two elderly couples, a Christian and a Muslim one, on their way back home from work in the fields: when the Muslim couple is travelling, she explained, the man is riding a donkey, and the woman is leading the animal. With Christian couples, it's the woman who rides the donkey, and the man walks by her side (Interview 28, Satovcha 2005). My respondents compared Muslim women to "slaves" or "bees in a hive", with men taking advantage of their hard work. According to Christians, Muslims struggle economically because they have many children, a marker of being "uncultured". This seems unwarranted, as even my respondents note that Muslim and Christian families in the Rhodopes increasingly have the same number of children (two or three):

M.: Their marital relations are different as well.

M.L.: How?

M.: Well, it's like [the relationship] between a master and his slave woman. I'm a man, and you? You're nobody. They complain that they have too much work and no time for themselves, having too many children. [Though] recently they, too, tend to have two or three children at the most. Uncultured. Our parents used to be like that, too. (W, Ch, Interview 33, Garmen 2006)

My respondents believe that Muslim men have double moral standards as they keep their women isolated while enjoying a libral lifestyle. For instance, Muslim men allegedly often have lovers outside of the marriage, whereas Muslim women must be docile despite their humiliations:

Y.: As a rule, women are kept cloistered in the Muslim religion. I mean, the Qur'an says that a man may have as many wives as he pleases. So for them, a woman is a second-class person, in a sense she isn't human. (W, CH, Interview 28, Satovcha 2005)

V.: I mean, the prohibitions in the Qur'an... A woman should stay at home. She's lucky if she doesn't get beaten up in the evening.

M.L.: Meaning what?

V.: He might beat her up in the evening if he feels like it. It doesn't matter if she's been working hard all day, in the evening he may beat her all the same. She must be silent. No right to complain. 
Y.: When the husband comes home late, late at night, and she's already in bed, she must get up and serve him a meal when he comes home.

V.: They even wash their [husbands'] feet.

\section{M.L.: They still do that?}

V.: In some families they do. For sure. When he comes home, she has to wash his feet, put food on the table, wish him a good evening. Even though he may have been with his lover in a restaurant ten minutes before, that's what it's like... (Women, Ch, Interview 28, Satovcha 2005)

The respondent compares the current situation of Muslim women to the situation of Christian women in the Middle Ages, when, she claims, they were seen as inferior to men:

H.: Muslims believe that women are inferior to men, which is not the case among Christians. Though there were times during the Middle Ages when women were considered inferior. $(\mathrm{M}, \mathrm{Ch}$, Interview 47, Garmen 2006)

Some of my respondents believe that the subordinated social status of Muslim women is a matter of Islamic principles. Others argue that the problem is unrelated to religion, and stems from the primitive ways of the Muslim men. In practical terms, they say, the exact source of those prohibitions makes no difference to Muslim women:

K.: I think it's a matter of principle with them that women are born in sin. That's what it's like with Muslims. She was conceived in sin, and that's why things are like that. The big things, the important things are up to the man to decide. That's destiny in their religion. (W, Ch, Interview 37, Garmen 2006)

M.L.: Could you tell me, roughly, which things are a matter of religious rules, and which get imposed by the men?

S.: What is it that they impose? Things like covering her body - that's not required anymore. Cover yourself, don't talk to men. How primitive. It's nothing to do with religion. How could that be a religious matter?!

M.L.: Do the women know that it's not a matter of religion?

S.: Even if they do, nobody wants their opinion. (W, Ch, Interview 35, Garmen 2006)

Christians often discuss the culture of the local Muslims in terms of sweeping generalizations, describing it as primitive and unexamined. One of my respondents was scandalized by the fact that Muslim women working in the fields took care to cover their faces but ignored the fact that their bare breasts were showing: 
S.: My uncle had some farmland. At harvest time he used to take the kadǔnas from Debren to his field, all neat and covered up. They wouldn't come and sit by the chorbadzhiya ${ }^{442}$ where he's having his meal, where we were having meals with my uncle and his children. They were accompanied by a Turkish man, they called him "Dragomanin". He was their minder, to make sure they were not alone. So her mouth is covered, but her [blouse] is all unbuttoned, she's flashing her breasts. My uncle said, "Look," he says, "they are simple folk. She's covered her mouth but her blouse is unbuttoned, her breasts are showing”. That's what I mean, I find that primitive. That's how I see it. (W, Ch, Interview 35, Garmen 2006)

Another respondent, a former Communist from Garmen, believes that Muslim men are particularly interested in sexual experiences and prefer curvaceous women:

V.: Hristo, listen and learn why it is that Muslims prefer well-rounded women.

M.L.: Why?

W.: There must be a reason. They're experts in matters of sexuality. And that ...

M.L.: I can't see the connection.

W.: It's more pleasurable that way. Fatter women are tighter down there. (M, Atheits from Christian background, Interview 47, Garmen 2006)

Body covering, particularly kerchiefs, are frequently referred to as symbols of the subservient status of Muslim women. My female respondents interpreted the traditional costumes of Pomak women as a sign of male dominance, because Muslim men wear no distinguishing clothes:

Man H.: I don't like this idea that women should wear kerchiefs. Muslim women can only show themselves to their husbands, brothers, fathers and mothers at home. For everybody else, she must wear a kerchief. There are different types of kerchiefs for unmarried women, married women, with different colours, like in Ribnovo for instance ...

Sofiya: Younger women, older women. Obviously, the younger women will be looking for more colourful ones. Older women wear different ones.

M.L.: Like what?

Woman S.: The same type, but the colors are more muted.

M.L.: Do they tie them the same way?

442 A prosperous peasant who owns his own farm; a person who can afford to eat well, literally "one who can afford to eat chorba", a thick soup. 
H.: You tie them the same way. If you go to Ribnovo you won't even know which men belong to a different religion, but it's obvious with the women.

S.: They [the men] dress as they please, and they go wherever they please. Only the women are oppressed. (Christians, Interview 47, Garmen 2006)

M.L.: If that's the case, why do women have to wear zabradki?

V.: That's so they don't get sullied by other men's gaze. She offers herself to him only. How could a stranger look at her?! Only her husband has the right to enjoy her. (M, Atheist from Christian background, Interview 48, Garmen 2006)

The traditional costume worn by Muslim women in the Rhodopes is also treated as a sign of Turkish domination, reminding Christians of the centuries-long history of Ottoman rule. Accordingly, the loose-fitting trousers worn by Muslim women in some towns and villages in the Rhodopes are called shalvari or poturi.

M.: Their faith says that a woman's mouth should be covered. Today, young people no longer do that. Young girls wear skirts so short you can see their bottoms. And besides... that's their faith, they used to wear poturachi and shalvari.

M.L.: Poturi?

M.: Poturi is another word for shalvari.

M.L.: Are they called poturi because that's Turkish or...?

M.: Yes. It’s Turkish for shalvari. (W, Ch, Interview 34, Garmen 2006)

My Christian respondents consider Muslim women who wear the traditional costume as unsophisticated, unlike Muslim women wearing European clothes. The following respondent believes most women in Satovcha, where she lives, are in the former category (though her opinions are not consistent, as shown later in this chapter), whereas the Muslim women in Kochan, a village a few miles from Satovcha, are more modern:

V.: In that [neighbouring village - M.L.] the people are, how shall I put it, very modern... I'm talking about their appearance. Whereas here you get the Oriental thinking. Here, the older women are gossiping away about short skirts, and there, they say, "My granddaughter is wearing more stylish clothes [than yours], her skirt is shorter, her clothes are more stylish". (W, Ch, Interview 28, Satovcha 2005)

M.: They [the Pomaks - M.L.] know that brides all over the world wear white. And they do the same. They know it's the same in Turkey, and they realize that in some ways they are backward.

M.L.: But generally speaking, are shalvari worn in Turkey? 
M.: Only among the more backward folk. But most people are Europeans. (W. Ch, Interview 23, Garmen 2006)

This particular way of thinking about the traditional Pomak costume was propagated in Bulgaria under the Communist regime.

The archaisms present in the spoken language of some the local Muslims in Satovcha (particularly the forms used for addressing one's elders) are also seen as a symptom of Pomak backwardness:

Woman 2: Other than that they're... how shall I put it... they are very modern. I'm talking about their appearance. But their ways are different. Here, they address people as "daicho" rather than "vujcho". (W, Ch, Interview 28, Satovcha 2005)

According to this respondent, the differences in women's fashion dividing Satovcha and Kochan stem from the fact that the people in Satovcha seek to emphasize their Muslim identity by wearing traditional Muslim clothes given the strong Christian presence in the area.

Although references to the traditional costume turned up frequently in conversations about Pomak customs, fashion was not regarded as very important. In Christian narratives Muslim women can be portrayed as culturally inferior regardless of whether they cover their bodies or wear "European" clothes. Women who wear traditional clothes are judged to be primitive and unsophisticated; those who wear European-style clothes are dismissed as hypocrites. Whenever my respondents realized that their comments were politically incorrect they usually attempted to revise their comments, and to present themselves as being tolerant and openminded. This is apparent in the following conversation, where the respondent makes a negative comment about the indecent, revealing clothes worn by Muslim girls, and then backtracks to avoid sounding judgemental:

V.: Though if they were really so religious inside they wouldn't wear short skirts, they wouldn't smoke cigarettes in restaurants or walk around with bare midriffs, because all those things are completely forbidden in their religion.

M.L.: But they don't observe those prohibitions?

W.: No, just look at them. Just go outside and you'll see this for yourself.

M.L.: I can't be sure those are not Christians.

V.: No. Nothing of the sort. They wear skimpier clothes than our girls. Than Christian girls. That's the fashion.

Iordanka: But we don’t think that's wrong.

V.: They're young. They like it this way. 
Y.: They like the way they dress. Let those children wear nice clothes.

V.: Unlike the elders, who disapprove of that. Some older people, particularly Muslim people, don't accept that.

M.L.: And the hodzhas?

Y.: Oh, the hodzhas are dead set against it, but they're quiet. There's nothing they can do! (Women, Ch, Interview 28, Satovcha 2005)

A few minutes later the same respondents were discussing a conversation between two hodzhas who feared that divine punishment, such as floods or hailstorms, could be visited on them because Muslim women were wearing European-style clothes. They discuss those fears in an ironic tone, despite having themselves criticized girls with bare midriffs minutes before:

V.: I see nothing [wrong - M.L.] with the hodzha. I mean, the hodzha is a very nice man and ... I mean, he's my age. He walks into a restaurant and looks around. One evening I listened to them, they were sitting at the next table, two hodzhas, very pious men. One of them even said "Mark my words, those bare midriffs and short skirts will bring hail, floods”. They think the current floods are punishments sent by Allah...

Yordanka: They believe strongly that the floods are God's way of punishing them for their lack of faith, and for failing to cover their bodies. Um, we are no different... And I think it's wrong to show your bare midriff. (Women, Ch, Interview 28, Satovcha 2005)

As this material shows, evidence for the supposedly "Oriental” nature of Pomak thinking boils down mostly to predictable, imitative and contradictory rationalizations reflecting the stereotypical nature of Christian thinking about Pomak customs. In many ways those notions are comparable to popular European stereotypes about Muslim minorities, where a sense of subjective superiority is generated by contrasting the backward Muslims with the modern Europeans. In this narrative, "schism and heresy arguably make members of the same community more other than the Others" (Benedyktowicz 2000, p. 41, translated from Polish).

What makes my Christian respondents different from the average European is an underlying sense of insecurity as their judgements tend to reflect the very things they find embarrassing about themselves. This suggests a cognitive dissonance caused by the fact that Christians have assimilated certain elements of everyday Ottoman culture. "The rejection of Ottoman past is undoubtedly one of the most interesting specific characteristics in the history of the Bulgarian nation" (Lori 2002, p. 8, translated from Bulgarian). In the comments of my respondents, this is expressed by the symbolic legend of Bulgarians getting rid of their fez hats following the end of Ottoman occupation: 
Woman 1: When Bulgaria became independent, and Bulgarian troops came back and were welcomed here by our people ... You know, where ... [The respondent speaks indistinctly - M.L.] and our Bulgarians were wearing fez hats, Turkish hats, and when the Bulgarians were coming ... [they would say - M.L.] "Throw this hat away. Now we wear Bulgarian hats, not Turkish ones". (W, Christian, Interview 25, Satovcha 2005)

The claims about the supposed Oriental characteristics of the Pomaks should be examined in connection with statements concerning the Ottoman legacy, a task which requires further research and goes beyond the scope of this book. 